\title{
Evaluación de la eficacia de tratamientos en el incremento de la durabilidad de una calcarenita bioclástica (Granada, España)
}

\section{Effectiveness of stone treatments in enhancing the durability of bioclastic calcarenite in (Granada, Spain)}

\author{
A. Luque ${ }^{(*)}, \underline{G}_{\text {. Cultrone }}^{(*)}$, E. Sebastián ${ }^{(*)}$ y O. Cazalla ${ }^{(* *)}$
}

Recepción/Received: 8-V-07

Aceptación/Accepted: 23-XI-07

Publicado online/Online publishing: 1-XII-08

\section{RESUMEN}

La calcarenita de Santa Pudia es uno de los materiales rocosos de construcción más empleados en las edificaciones monumentales de la ciudad de Granada (España). Se ha evaluado la compatibilidad de diversos productos de tratamiento (de consolidación y/o hidrofugación) con esta calcarenita y como son capaces de mejorar su durabilidad. Para ello, se han realizado dos fases de envejecimiento acelerado: la primera tenía el objetivo de acercar el material de cantera sin alterar ("sano") a las condiciones reales del material puesto en obra y actualmente deteriorado; la segunda, efectuada después de aplicar los tratamientos sobre la calcarenita deteriorada, con el fin de determinar su grado de eficacia. Se ha podido comprobar que aunque, en general, todos los productos de tratamiento seleccionados (Tegosivin HL100, Silo 111, Estel 1100 y Tegovakon V) mejoran las propiedades del material frente al deterioro y apenas modifican sus parámetros cromáticos, el más eficaz es el Tegovakon $\mathrm{V}$ ya que es el que proporciona mejores resultados frente a los ensayos hídricos en este litotipo calcáreo.

Palabras clave: calcarenita, caracterización, durabilidad, Patrimonio Arquitectónico.

\section{SUMMARY}

Santa Pudia limestone, a biocalcarenite highly sensitive to decay, is one of the most commonly used building materials in historical monuments in the city of Granada, Spain. The compatibility between a variety of stone treatments (consolidants and/or water repellents) and this calcarenite was analyzed and the resulting improvement in durability assessed. To this end, a two-stage accelerated ageing process was implemented. In the first, freshly quarried, undamaged specimens were altered to resemble the weathered stone in buildings. The second was conducted after applying the various treatments to the artificially aged stone to test their effectiveness. While all the treatments studied (Tegosivin HL100, Silo 111, Estel 1100 and Tegovakon $V$ ) enhanced stone resistance to decay while barely affecting chromatic parameters, the most effective was Tegowakon $V$, as it provided the best results in the hydric tests on the limestone.
Keywords: calcarenite, characterization, durability, Architectural Heritage.

\footnotetext{
(*) Departamento de Mineralogía y Petrología, Facultad de Ciencias, Universidad de Granada (Granada, España).

(**) Centro de Instrumentación Científica, Universidad de Granada (Granada, España).
} 


\section{INTRODUCCIÓN}

Un material de construcción puede presentar un deterioro más o menos acusado dependiendo de las condiciones ambientales a las que se encuentre expuesto (1). Ya en la antigüedad se intentaba solucionar el progresivo envejecimiento de los materiales de construcción presentes en los edificios y monumentos mediante la aplicación de sustancias animales o vegetales como la cera de abeja, aceites y resinas (2), pero sin un conocimiento sistemático de los efectos que podía causar su aplicación. Fue con la llegada de la revolución industrial a finales del siglo XVIII cuando se intensificó la exigencia de proteger los monumentos de los nuevos agentes de deterioro que dicha actividad creaba. El desarrollo de costras negras era y es una de las formas macroscópicas de alteración más evidentes y extendidas $(3,4)$. Por ello, la industria química empezó a proporcionar una nueva serie de productos aptos para salvaguardar los monumentos del deterioro (5). Aunque en la actualidad son numerosas las investigaciones acerca del uso de tratamientos de consolidación y protección sobre materiales pétreos (6-12), la gran variedad de productos de consolidación y/o hidrofugación existentes en el mercado genera incertidumbres a la hora de elegir el tratamiento más adecuado para un material de construcción determinado.

La calcarenita de Santa Pudia (conocida también con el nombre de Piedra Franca) es, sin duda, el material de construcción más utilizado en las edificaciones monumentales de Granada (España). La Catedral, el Palacio de Carlos V en la Alhambra, el Monasterio de San Jerónimo, el Hospital Real y la Real Chancillería son algunos de los monumentos más emblemáticos de la ciudad que están construidos con esta roca sedimentaria.

El hecho de ser un material tan ampliamente empleado en el patrimonio arquitectónico ha originado que haya sido estudiado en los aspectos que se refieren a su mineralogía, textura y propiedades físico-mecánicas. Se trata de una calcarenita bioclástica de edad Tortoniense rica en fragmentos de moluscos, equinodermos y foraminíferos. La matriz carbonatada es microesparítica y ocasionalmente presenta calcita secundaria. Otros componentes de carácter minoritario son el cuarzo, la biotita y los feldespatos $(14,15)$. Texturalmente es un material muy poroso, ya que suele alcanzar, y en algunos casos puntuales sobrepasar, el $30 \%$ de espacios vacíos en muestras recogidas en monumentos, con una cohesión escasa y presentar una resistencia a la compresión uniaxial de 13 MPa (15) determinada de acuerdo con la norma UNE 22185-85 (16). Muestra una gran sensibilidad al deterioro producida por fenómenos de contaminación, especialmente del tráfico (17), y por las rígidas condiciones climáticas que padece Granada, con fuertes oscilaciones

\section{INTRODUCTION}

The extent of decay in building materials depends on the environmental conditions to which they are exposed (1). Even in ancient times ways were sought to curb the progressive ageing of the materials used in buildings and monuments, and stone was often covered with organic substances such as beeswax, oils or resins (2), even though contemporary builders had no systematic understanding of the possible effects. The onset of the industrial revolution at the end of the $18^{\text {th }}$ Century intensified the need to protect historic buildings, particularly from the new agents of decay generated by industrial activities. To prevent the development of black crust, one of the most conspicuous and common macroscopic forms of damage $(3,4)$, the chemical industry is marketing a new series of products designed to protect monuments from this type of decay (5). Although a great deal of research is being conducted today on the use of different treatments to consolidate and protect building stone (6-12), the fact that there is such a wide range of consolidants and/or water repellents on the market breeds confusion around the choice of the most suitable treatment for a particular building material.

Santa Pudia calcarenite (also know as piedra franca) is by far the most widely used building material in the historic monuments of Granada, Spain. The Cathedral, the Palace of Charles $V$ on the Alhambra grounds, San Jeronimo Monastery, the Royal Hospital and the Royal Chancellery are all examples of emblematic buildings in the city that were built with this sedimentary rock.

Inasmuch as this material has been so widely used in Spain's architectural heritage, its mineralogy, texture and physical/mechanical properties have been amply studied. A Tortonian Stage bioclastic calcarenite, it is characterized by the abundance of broken calcareous remains of molluscs, echinoderms and foraminifers in its composition The carbonated matrix of this microsparitic stone occasionally contains secondary calcite. Its minority components include quartz, biotite and feldspars (14, 15), while its texture is very porous, with voids often accounting for up to and on occasion more than $30 \%$ of the volume in samples collected from monuments. It exhibits poor cohesion and a uniaxial compressive strength of 13 MPa (15), determined as specified in Spanish standard UNE 22-185-85 (16). Highly susceptible to pollution, especially traffic pollution (17), this calcarenite is also exposed to decay in Granada's severe climate, characterized by wide daily and seasonal fluctuations in temperature, with very low minimum temperatures in the winter 
térmicas diarias y estacionales, inviernos con temperaturas mínimas acusadas y veranos muy calurosos. En efecto, si se comparan muestras de cantera no alteradas con otras procedentes de los monumentos, se observan importantes diferencias a nivel textural que se manifiestan con sustanciales modificaciones tanto en el rango de distribución de poros como en el incremento de la porosidad $(15,17)$.

Debido a las variaciones que sufre la calcarenita de Santa Pudia en su textura y en sus propiedades físicas una vez puesta en obra, es necesario conocer qué productos de tratamiento son los más compatibles con este material de construcción y en qué medida mejoran su durabilidad. Se pretende en este trabajo, por tanto, determinar el grado de efectividad de diversos productos consolidantes e hidrofugantes sobre muestras de piedra de cantera previamente alteradas en el laboratorio, con el fin de que se asemejen a las que se encuentran en los edificios históricos.

\section{MATERIALES Y MÉTODOS}

La metodología seguida en este trabajo se puede resumir en las siguientes fases:

1) determinación de los parámetros hídricos de muestras de cantera;

2) envejecimiento acelerado de las muestras de cantera y evaluación de los cambios de las propiedades hídricas;

3) aplicación de productos de tratamiento a algunas de las muestras anteriormente alteradas (en la fase 2) y posterior etapa de ciclos de envejecimiento acelerado;

4) estudio de los parámetros hídricos tras finalizar estos últimos ensayos de envejecimiento.

Durante la segunda etapa de envejecimiento acelerado, se han incluido a título comparativo, tres probetas de muestras "sanas" de calcarenita (utilizadas como blanco) y otras nueve probetas degradadas (tres de cada uno de los ensayos de envejecimiento realizados) pero sin tratar.

Mediante los ensayos hídricos se ha estudiado la capacidad de absorber y evaporar el agua por parte de las diferentes calcarenitas (sanas, degradadas y degradado-tratadas) (18-19). Los ensayos abordados han sido los de absorción y desorción libre de agua y saturación al vacío, de acuerdo con las recomendaciones NORMAL 7/81 (20), NORMAL 29/88 (21) y RILEM (22). El número total de probetas ensayadas ha sido 84 ( 3 en blanco, 9 envejecidas y $\sin$ tratar y 72 envejecidas y tratadas).

Teniendo en cuenta los factores climáticos y ambientales de la ciudad de Granada, los ensayos de envejecimiento elegidos han sido los de hielo-deshielo, de acuerdo con la and very warm summers. A comparison of freshly quarried stone to samples from monuments reveals significant textural differences in both pore size distribution and total porosity, which is higher in the latter $(15,17)$.

Given that the texture and physical properties of Santa Pudia calcarenite change when it is used in construction, the treatments that are most compatible with this stone need to be identified and their capacity to enhance its durability ascertained. This study aims to assess the contribution of a variety of consolidants and water repellents to the protection of quarry stone samples previously subjected to laboratory-induced decay to obtain a material as similar as possible to the stone found in historic buildings.

\section{MATERIALS AND METHODS}

The procedure followed in this study is summarized below:

1) determination of quarry sample water sorption parameters;

2) accelerated ageing of the quarry samples and determination of the changes in sorption;

3) treatment of the artificially aged samples, followed by a second round of accelerated ageing;

4) sorption testing upon conclusion of the second stage of ageing.

In addition to the previously aged and treated specimens, three freshly quarried specimens of calcarenite (used as controls) and nine untreated artificially aged specimens (three for each ageing proceudre) were included in the second round of accelerated ageing for comparison.

Water sorption in the control and treated and untreated artificially aged calcarenite specimens (18-19) was determined with free water absorption and desorption as well as vacuum saturation tests, pursuant to Italian (NORMAL 7/81 (20), NORMAL 29/88 (21)) and international (RILEM (22)) recommendations. In all, 84 specimens (3 controls, 9 aged and untreated and 72 aged and treated samples) were studied.

Freeze-thaw cycle trials as specified in Spanish standard UNE 67-028-84 (23), salt crystallization trials pursuant to Spanish standard UNE 7-136-58 (24) and $\mathrm{SO}_{2}$-polluted 
norma UNE 67-028-84 (23), los de cristalización de sales (norma UNE 7-136-58) (24) y el de introducción del material en una cámara con atmósfera contaminada con $\mathrm{SO}_{2}$ (norma DIN 50018) (25), utilizándose en cada uno de los ensayos un total de tres probetas cúbicas de $5 \mathrm{~cm}$ de arista. La simulación de la atmósfera contaminada se ha llevado a cabo en una cámara climática modelo Kesternich durante 30 días. Las condiciones del ensayo han sido: temperatura de $25{ }^{\circ} \mathrm{C}$, humedad relativa del $50 \%$ e introducción de 400 ppm de $\mathrm{SO}_{2}$ en la cámara en cada ciclo diario.

Durante los ensayos de envejecimiento acelerado se ha observado y documentado la evolución del deterioro de las probetas (desarrollo de fisuras, disgregaciones, etc.) y su variación de peso y color. La unión entre los bioclastos tras los ensayos de deterioro acelerado y/o la posterior aplicación de los productos de tratamiento han sido visualizados y evaluados mediante microscopía electrónica de barrido (MEB) en un microscopio Zeiss DMS 950.

Para la cuantificación de los cambios en la cromaticidad y la luminosidad de las calcarenitas durante las diferentes fases del procedimiento se ha utilizado un colorímetro Minolta CR 210.

Los productos de tratamiento elegidos han sido uno específico de consolidación (Tegovakon V), dos de hidrofugación (Tegosivin HL 100 y Silo 111) y uno mixto con ambas características, consolidante más hidrofugante (Estel 1100). En la tabla 1 se recogen la naturaleza y características de los cuatro productos. Las metodologías de aplicación han sido mediante inmersión total del material pétreo en el producto, o bien la de pulverización del producto sobre las superficies de la probeta de piedra, de acuerdo con los procedimientos recomendados en la bibliografía $(6,26-29)$. atmosphere trials as per German standard DIN 50018 (25) were conducted to simulate the weather and environmental conditions prevailing in Granada. Three $5 \mathrm{~cm}$ edge cubic specimens were used in each trial. The polluted atmosphere was simulated in a $\mathrm{CO}_{2}$-saturated climatic chamber (Kesternich), where specimens were stored for 30 days at a temperature of $25^{\circ} \mathrm{C}$ and a relative humidity of $50 \% ; 400$ ppm of $\mathrm{SO}_{2}$ were pumped into the chamber every 24 hours.

All visible signs of decay in the test samples (cracking, disaggregation and so on) and variations in weight or colour were recorded during accelerated ageing. After accelerated ageing and/or the subsequent application of treatments, the inter-bioclastic bonds were visualized and assessed under a Zeiss DMS 950 scanning electron microscope.

A Minolta CR 210 colorimeter was used to determine the changes in the chromaticity and lightness of the calcarenite samples during the various experimental stages.

The following treatments were applied: one consolidant (Tegovakon V), two water repellents (Tegosivin HL 100 and Silo 111) and one consolidant + water repellent combination (Estel 1100). The composition and characteristics of the four products are given in Table 1. The treatments were applied either by submerging the stone in or spraying it with the product, in accordance with the recommendations set out in the literature $(6,26-29)$.

Tabla 1 / Table 1

Características de los productos aplicados.

Characteristics of the treatments tested.

\begin{tabular}{|c|c|c|c|c|}
\hline $\begin{array}{l}\text { Producto } \\
\text { Product }\end{array}$ & $\begin{array}{l}\text { Fabricante } \\
\text { Manufacturer }\end{array}$ & $\begin{array}{l}\text { Propiedades } \\
\text { Properties }\end{array}$ & $\begin{array}{l}\text { Dilución (\%) } \\
\text { Dilution (\%) }\end{array}$ & $\begin{array}{l}\text { Composición } \\
\text { Composition }\end{array}$ \\
\hline $\begin{array}{l}\text { Tegosivin } \\
\text { HL100 }\end{array}$ & Th. Goldschmidt, A.G. & $\begin{array}{l}\text { hidrofugante } \\
\text { water repellent }\end{array}$ & $\begin{array}{l}10 \text { (etanol) } \\
10 \text { (ethanol) }\end{array}$ & $\begin{array}{l}\text { oligómero de siloxano etoxifuncional } \\
\text { ethoxy-siloxane oligomer }\end{array}$ \\
\hline Silo 111 & C.T.S., S.r.I. & $\begin{array}{l}\text { hidrofugante } \\
\text { wate repellent }\end{array}$ & $\begin{array}{l}\text { incluye disolvente } \\
\text { includes solvent }\end{array}$ & $\begin{array}{l}\text { organosiloxano oligomérico } \\
\text { oligomeric organosiloxane }\end{array}$ \\
\hline Estel 1100 & C.T.S., S.r.l. & $\begin{array}{l}\text { consolidante }+ \text { hidrofugante } \\
\text { consolidant }+ \text { water repellent }\end{array}$ & $\begin{array}{l}\text { incluye disolvente } \\
\text { includes solvent }\end{array}$ & $\begin{array}{l}\text { ester etílico del ácido silícico y } \\
\text { polisiloxano oligomérico } \\
\text { silicic acid, ethyl ester and } \\
\text { oligomeric polysiloxane }\end{array}$ \\
\hline Tegovakon V & Th. Goldschmidt, A.G. & $\begin{array}{c}\text { consolidante } \\
\text { consolidant }\end{array}$ & $\begin{array}{l}25 \text { (etanol) } \\
25 \text { (ethanol) }\end{array}$ & $\begin{array}{l}\text { ester de sílice y metilsiloxano } \\
\text { silica ester and methyl siloxane }\end{array}$ \\
\hline
\end{tabular}




\section{RESULTADOS Y DISCUSIÓN}

\subsection{Parámetros hídricos de muestras de cantera}

La calcarenita de la cantera de Santa Pudia presenta una elevada velocidad de absorción de agua, ya que en apenas 1 minuto llega casi a saturarse, y su incremento máximo de peso alcanza el $18 \%$. En contraposición, su cinética de secado es algo lenta (Figura 1), lo que induce a una cierta retención de agua en su interior que en algunos casos (por ejemplo, si están presentes sales disueltas en el agua) puede resultar perjudicial para su durabilidad (30). El coeficiente de saturación medido es del $74 \%$, mientras que la porosidad accesible al agua es del $21 \%$. Los valores de densidad calculados son: $2,00 \mathrm{~g} \mathrm{~cm}^{-3}$ para la densidad aparente y $2,50 \mathrm{~g} \mathrm{~cm}^{-3}$ para la densidad real.

\section{RESULTS AND DISCUSSION}

\subsection{Water sorption in quarry samples}

Santa Pudia calcarenite was found to have a very high water absorption rate, attaining near saturation and an $18 \%$ weight gain in just one minute. By contrast, its slow desorption (Figure 1), with water being retained inside the stone, may under some circumstances (if the water carries dissolved salts, for instance) adversely affect durability (30). The saturation coefficient was found to be $74 \%$ and open porosity $21 \%$. The bulk and real density values recorded were 2.00 and $2.50 \mathrm{~g} \mathrm{~cm}^{-3}$, respectively.

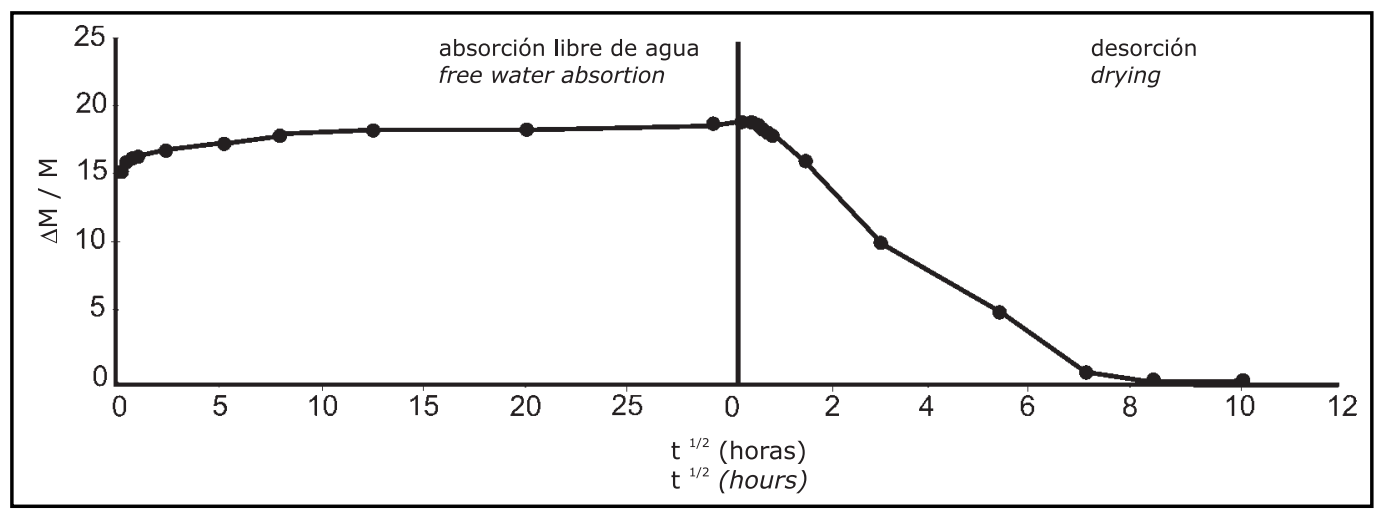

Figura 1. Curva de absorción y desorción libre de agua de la calcarenita de Santa Pudia. Incremento de peso $(\Delta \mathrm{M} / \mathrm{M})$ versus la raíz cuadrada del tiempo expresada en horas $\left(\mathrm{t}^{1 / 2}\right)$ Cada una de las curvas recoge el valor medio de los resultados de tres probetas.

Figure 1. Free water absorption and desorption curves for Santa Pudia calcarenite. Increase in weight $(\Delta M / M)$ against the square root of time in hours $\left(t^{1 / 2}\right)$.

Values represent the mean of three replicates.

\subsection{Proceso de envejecimiento acelerado de muestras de cantera y variación de las propieda- des hídricas}

El ensayo de hielo-deshielo no ha sido muy dañino para la calcarenita de Santa Pudia. Durante el proceso, las variaciones de peso han sido mínimas y al final del ensayo se ha podido observar cómo en todos los casos la pérdida de peso ha sido casi nula $(<0.1 \%)$. Visualmente el deterioro que se ha producido es de escasa intensidad; lo único que se ha observado han sido fragmentos muy pequeños de material disgregado depositado en el fondo del recipiente donde se habían colocado las muestras para el desarrollo de este ensayo.

La mayoría de las calcarenitas sometidas a ensayo de cristalización de sales han sufrido un ligero incremento de peso ( $<2.5 \%$ en peso) en los primeros ciclos. Este incre-

\subsection{Accelerated ageing of quarry samples and variation in water sorption}

The Santa Pudia calcarenite was scantly damaged by the freeze-thaw test. Only minor weight variations were observed during the process, while weight loss at the end of the test was nearly negligible $(<0.1 \%)$. The visual damage was likewise slight, consisting in the detachment of some very small fragments that feel to the bottom of the flask where the samples were kept during the procedure.

Most of the calcarenite specimens subjected to salt crystallization exhibited a slight weight gain $(<2.5 \%)$ in the first few cycles due to the precipitation in pores and 
mento podría explicarse por la cristalización de una parte de la solución de sulfato sódico en los poros y fisuras. Algunas muestras, una vez superado el $5^{\circ}$ ciclo, han empezado a perder gradualmente peso hasta el final del ensayo, hecho que se ha manifestado macroscópicamente en forma de arenizaciones, redondeamiento de aristas y picaduras. De todas maneras, en ningún caso se ha llegado a la destrucción total de las probetas de calcarenitas.

El ensayo de alteración en atmósfera contaminada por $\mathrm{SO}_{2}$ no ha causado modificaciones macroscópicas apreciables a simple vista en las calcarenitas, ni se han registrado variaciones de peso. Únicamente cabe destacar un ligero oscurecimiento de la superficie de las probetas que puede atribuirse a un inicio de descohesión y al desarrollo de pátinas de alteración de yeso (Figura 2). cracks of some of the sodium sulphate in solution. After the $5^{\text {th }}$ cycle, some of the samples showed a gradual weight loss that continued through the end of the procedure. The macroscopic symptoms were crumbling, edge rounding and nicking. None of the specimens was totally destroyed.

Exposure to an $\mathrm{SO}_{2}$-polluted atmosphere led to no macroscopic changes detectable with the naked eye, nor were any weight variations recorded. The only visible change was a slight darkening of the sample surfaces, perhaps as a result of incipient granular disintegration and the development of gypsum patinas (Figure 2).

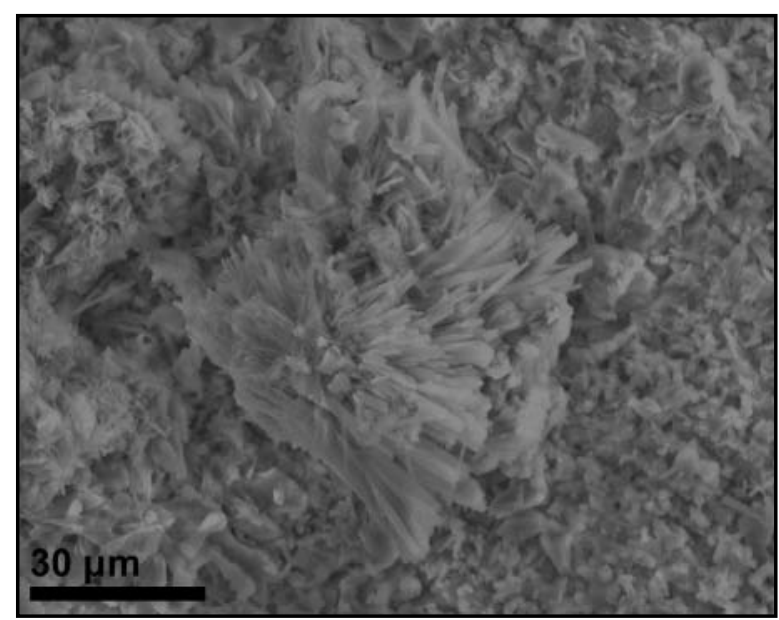

Figura 2. Microfotografía al MEB de cristales aciculares de yeso que se han desarrollado en la calcarenita sometida a ensayo de atmósfera contaminada con $\mathrm{SO}_{2}$.

Figure 2. SEM micrograph of needle-like gypsum crystals forming on calcarenite subjected to $\mathrm{SO}_{2}$ pollution.

En general, la cinética frente al agua de todas las muestras envejecidas y antes de serles aplicados los productos de tratamiento ha sido muy similar (Figura 3). La única diferencia que se aprecia es la lenta desorción que presentan el conjunto de muestras contaminadas por $\mathrm{SO}_{2}$ respecto a las alteradas mediante ciclos de hielo-deshielo y de cristalización de sales. Cabe recordar que el mayor deterioro se había producido en las calcarenitas sometidas al ensayo de cristalización de sales, seguidas en esta intensidad de deterioro por las que sufrieron los ciclos de hielo-deshielo $\mathrm{y}$, finalmente por las contaminadas por $\mathrm{SO}_{2}$; ello puede haber dado lugar a un menor desarrollo de fisuras en estas últimas. Las fisuras, conectando los poros de las calcarenitas habrían influido significativamente en la cinética de secado. Por otra parte, la presencia de una sutil capa de cristales de yeso en la superficie de las calcarenitas puede haber contribuido a obstaculizar el movimiento del agua hacia el exterior y modificar su dinámica de evaporación.
As a rule, prior to treatment all the artificially aged samples reacted similarly to exposure to water (Figure 3). The only noticeable difference was that desorption was much slower in the specimens subjected to $\mathrm{SO}_{2}$ pollution than in the freeze-thaw- and salt crystallization-aged samples. Salt crystallization was the procedure that caused the greatest damage to the samples, followed, in terms of intensity of decay, by the freeze-thaw cycle and $\mathrm{SO}_{2}$ pollution. This may explain why cracking was less extensive in this last series of specimens. Cracks, which interconnect the pores in the calcarenite, would have a significant effect on drying kinetics. Finally, the presence of a thin layer of gypsum crystals on the surface of the samples may have hindered water egress and altered evaporation dynamics. 


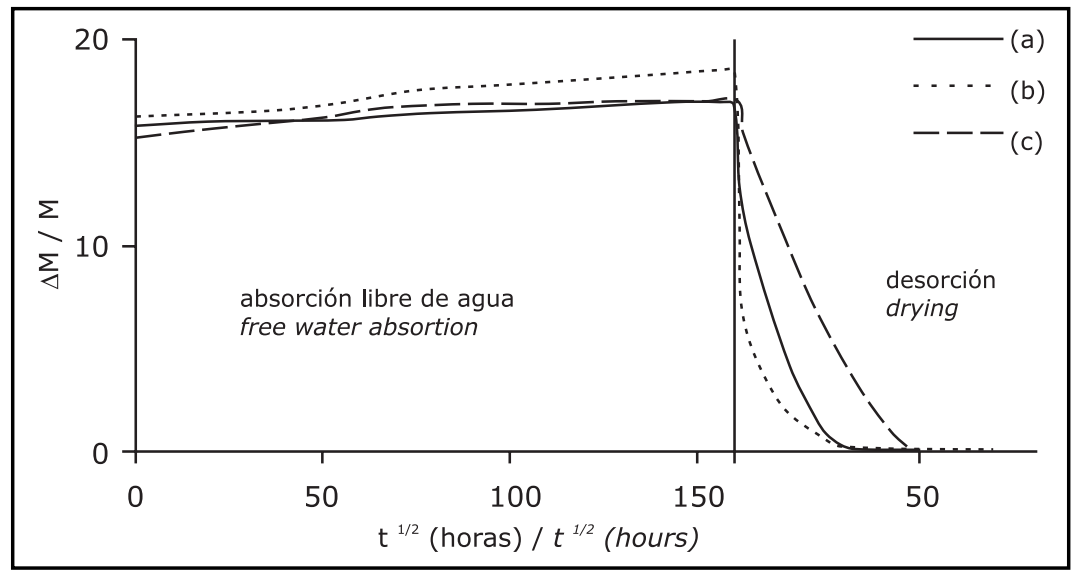

Figura 3. Curvas de absorción y desorción libre de agua de las muestras no tratadas y sometidas a ciclos de hielo-deshielo (a), cristalización de sales (b) y atmósfera contaminada por $\mathrm{SO}_{2}$ (c). Incremento de peso $(\Delta \mathrm{M} / \mathrm{M})$ versus la raíz cuadrada del tiempo expresada en horas ( $\left.t^{1 / 2}\right)$. Cada una de las curvas recoge el valor medio de los resultados de ocho probetas.

Figure 3. Free water absorption and desorption curves for untreated calcarenite samples after

(a) freeze-thaw, (b) salt crystallization and (c) $\mathrm{SO}_{2}$ pollution ageing procedures. Increase in weight ( $\left.\Delta \mathrm{M} / \mathrm{M}\right)$ against the square root of time in hours $\left(t^{1 / 2}\right)$. Values represent the mean of eight replicates.

\subsection{Aplicación de productos de tratamiento a las muestras alteradas y nuevo proceso de envejeci- miento acelerado}

Se ha establecido el aumento en peso de las calcarenitas después de su impregnación con los productos de tratamiento, tanto por inmersión como por pulverización. Este aumento es consecuencia de la penetración y posterior polimerización de los productos en el interior de las probetas (Tabla 2) que se origina transcurridos 7 días.

\subsection{Treatment of artificially aged samples and second round of accelerated ageing}

After impregnation, weight gains were recorded in all the treated specimens, whether immersed or sprayed. This increase in weight was an indication that the treatments had successfully penetrated the samples and that polymerization had begun seven days after application (Table 2).

Tabla 2 / Table 2

Incremento de peso (en \%) de las calcarenitas tratadas y en las que previamente se habían efectuado ensayos de alteración acelerada. Leyenda: $\mathrm{i}=$ aplicación por inmersión; $\mathrm{p}=$ aplicación por pulverización; $\mathrm{T}_{\mathrm{V}}=$ Tegovakon $\mathrm{V}$; $\mathrm{E}_{1100}=$ Estel $1100, \mathrm{~S}_{111}=$ Silo $111 ; \mathrm{T}_{\mathrm{HL} 100}=$ Tegosivin HL100.

Weight gain (in \%) in treated calcarenite samples previously subjected to accelerated ageing. Legend: $i=$ immersion; $p=$ spray; $T_{V}=$ Tegovakon $V ; E_{1100}=$ Estel 1100, $S_{111}=$ Silo 111; $T_{H L 100}=$ Tegosivin HL100

\begin{tabular}{|l|c|c|c|c|c|}
\hline $\begin{array}{l}\text { Ensayo } \\
\text { Procedure }\end{array}$ & $\begin{array}{c}\text { Aplicación } \\
\text { Applied by }\end{array}$ & $\mathbf{T}_{\mathbf{V}}$ & $\mathbf{T}_{\mathbf{H L 1 0 0}}$ & $\mathbf{S}_{\mathbf{1 1 1}}$ & $\mathbf{E}_{\mathbf{1 1 0 0}}$ \\
\hline Cristalización de sales & $\mathrm{i}$ & 10 & 3 & 16 & 11 \\
Salt crystallization & $\mathrm{p}$ & 5 & 5 & 2.5 & 1.5 \\
\hline Hielo-deshielo & $\mathrm{i}$ & 8 & 8.5 & 4 & 8 \\
Freeze-thaw & $\mathrm{p}$ & 4.5 & 7 & 1.5 & 6 \\
\hline Contaminación por $\mathrm{SO}_{2}$ & $\mathrm{i}$ & 9 & 14 & 4 & 8.5 \\
$\mathrm{SO}_{2}$ pollution & $\mathrm{p}$ & 5 & 5.5 & 1.5 & 5.5 \\
\hline
\end{tabular}

Analizando la tabla es evidente que la cantidad de producto que se introduce por pulverización en el interior de las muestras es inferior que si el procedimiento es por inmersión, mientras que en función del tipo de aditivo empleado no se observa una tendencia definida. El mayor o menor deterioro de las muestras (sobre todo fisuras y grietas) influye en la cantidad de producto absorbido.
The data in the table show that more product penetrated the samples via immersion than via spray, while no clear patterns could be discerned in terms of treatment type. The degree of decay (particularly cracking) affected the amount of product absorbed. 
La aplicación de los productos de consolidación y/o protección mejoran la durabilidad de las calcarenitas. En concreto, el ensayo de hielo-deshielo muestra como las muestras tratadas con algún producto sufren un menor incremento de peso $(\Delta M / M)$, originado por la entrada de agua en las probetas al comenzar el ensayo, en comparación con la muestra utilizada como "blanco". Este hecho es más evidente si el producto aplicado es el Tegosivin $\mathrm{HL}$ 100 por pulverización (Figura 4a). Por otra parte las muestras tratadas con Tegovakon $\mathrm{V}$ por inmersión y Silo 111 son las que tienen el comportamiento más parecido a las muestras en blanco (Figura 4a). A simple vista no se han observado formas de deterioro en las probetas al finalizar los ciclos programados en este ensayo.

Las probetas tratadas con Estel 1100 y Tegovakon V y sometidas a los ciclos de cristalización de sales han mantenido una pauta inicial muy similar a la muestra sin tratar ("blanco", Figura 4b) ya que presentan una ligera ganancia de peso que se mantiene hasta el 70 ciclo, a partir del cual sufre una brusca pérdida de masa causada por el comienzo de su desmoronamiento, que en el $10^{\circ}$ ciclo es casi completo. Por el contrario, las muestras tratadas con Tegosivin HL 100 y Silo 111 han soportado sin daños apreciables todo el ensayo, manteniendo su peso en valores similares al inicial. Este comportamiento es lógico dado que ambos productos son hidrofugantes y su función es la de impermeabilizar las muestras, siendo evidente que al no entrar el agua, tampoco entrarán las sales solubles en el interior de las calcarenitas.
Calcarenite durability was improved by the application of consolidation and/or protection treatments. In the freeze-thaw trial in particular, absorption-mediated weight increase $(\Delta M / M)$ early in the procedure was lower in the samples treated with any of the products than in the control. This effect was most intense when treatment Tegosivin HL 100 was sprayed onto the specimens (Figure 4a). The samples immersed in Tegovakon $V$ or treated with Silo 111 were the ones that behaved most like the control samples (Figure 4a). No visible signs of damage were detected in the samples at the end of the trial.

The Estel 1100- and Tegovakon V-treated samples subjected to salt crystallization initially exhibited behaviour very similar to the untreated control sample (Figure $4 b$ ): a slight weight gain until the $7^{\text {th }}$ cycle followed by an abrupt decline in mass due to incipient collapse, which was nearly complete by the $10^{\text {th }}$ cycle. By contrast, the samples treated with Tegosivin HL 100 and Silo 111 resisted the saline attack with no appreciable damage, maintaining a nearly constant weight throughout. This was as expected, for these two products are water repellents which, by waterproofing the stone, obviously provide effective protection against soluble salts.
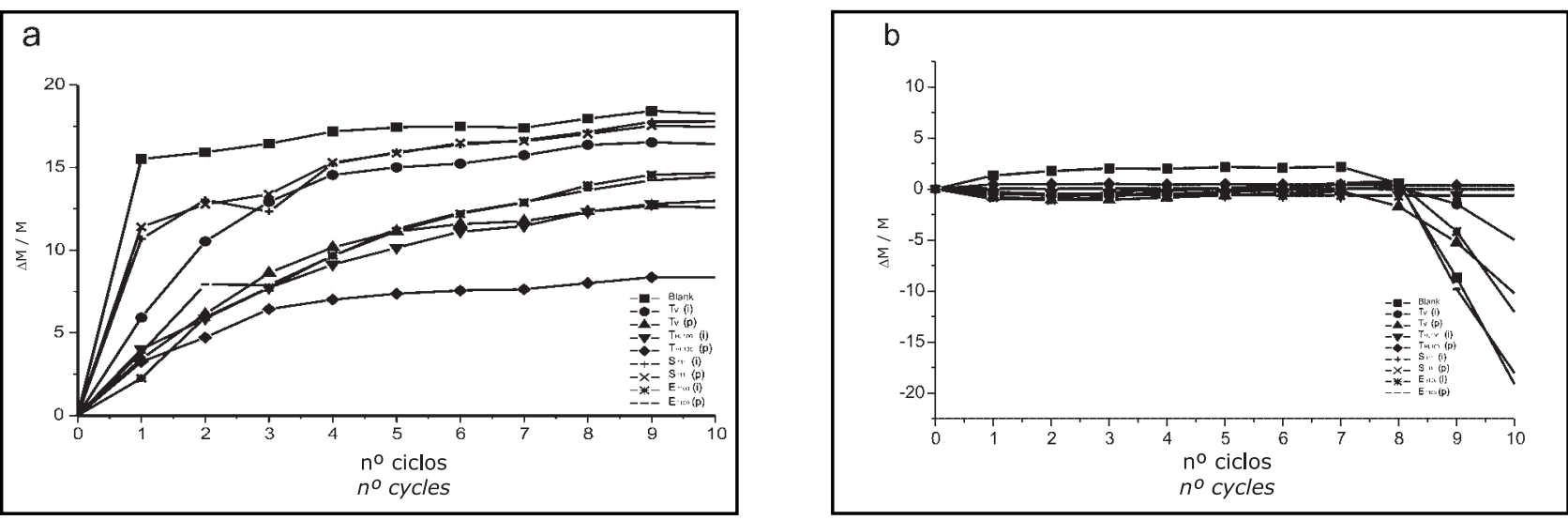

Figura 4. Variación del peso $(\Delta \mathrm{M} / \mathrm{M})$ de las muestras "en blanco" y tratadas con productos consolidantes y/o hidrofugantes a lo largo de ciclos de ensayos de hielo-deshielo (a), cristalización de sales (b). Cada una de las curvas recoge el valor medio de los resultados de tres probetas. Leyenda: $\mathrm{i}=$ aplicación por inmersión; $\mathrm{p}=$ aplicación por pulverización; $\mathrm{T}_{\mathrm{V}}=$ Tegovakon V; $\mathrm{E}_{1100}=$ Estel 1000, $\mathrm{S}_{111}=$ Silo $111 ; \mathrm{T}_{\mathrm{HL} 100}=$ Tegosivin HL100.

Figure 4. Variation in weight $(\Delta M / M)$ in control samples and samples treated with consolidants and/or water repellents during (a) freeze-thaw and (b) salt crystallization ageing procedures. Values represent the mean of three replicates. Legend: $i=$ immersion; $p=$ spray; $T_{V}=$ Tegovakon V; $E_{1100}=$ Estel 1100, $S_{111}=$ Silo 111; $T_{\text {HL100 }}=$ Tegosivin HL 100.

En general, el deterioro producido en las muestras ha sido motivado por la pérdida de fragmentos, observándose además picaduras superficiales y redondeamiento de
On the whole, damage in these samples consisted in detached fragments, although some surface nicking and edge rounding were also observed. A whitish film also 
aristas. También cabe destacar el desarrollo de una pátina blanquecina en la superficie de las probetas, debido a las sales cristalizadas como eflorescencias.

Finalmente, en el caso de las calcarenitas tratadas y sometidas a ensayo de contaminación por $\mathrm{SO}_{2}$ no se han apreciado variaciones en el peso, ni modificaciones o daños a nivel macroscópico de las probetas.

\subsection{Observaciones microscópicas de las calcareni- tas tratadas y alteradas}

La visualización en el MEB ha puesto de manifiesto que al someter las probetas a ciclos de envejecimiento acelerado, excepto en el caso de las introducidas en atmósfera contaminada por $\mathrm{SO}_{2}$, se produce una progresiva pérdida del producto aplicado, lo que origina que al finalizar el ensayo la superficie de las muestras no permanezca recubierta totalmente (Figura 5a). formed on the surface of the specimens as a result of salt efflorescence.

Lastly, the calcarenite samples subjected to $\mathrm{SO}_{2}$ pollution exhibited neither weight variations nor macroscopic alterations or damage.

\subsection{Microscopic observation of aged and treated samples}

The SEM images of the samples showed that when the specimens were subjected to accelerated ageing (except the $\mathrm{SO}_{2}$ pollution samples), the treatment applied was progressively worn away, so that by the end of the test some balding was detected (Figure 5a).
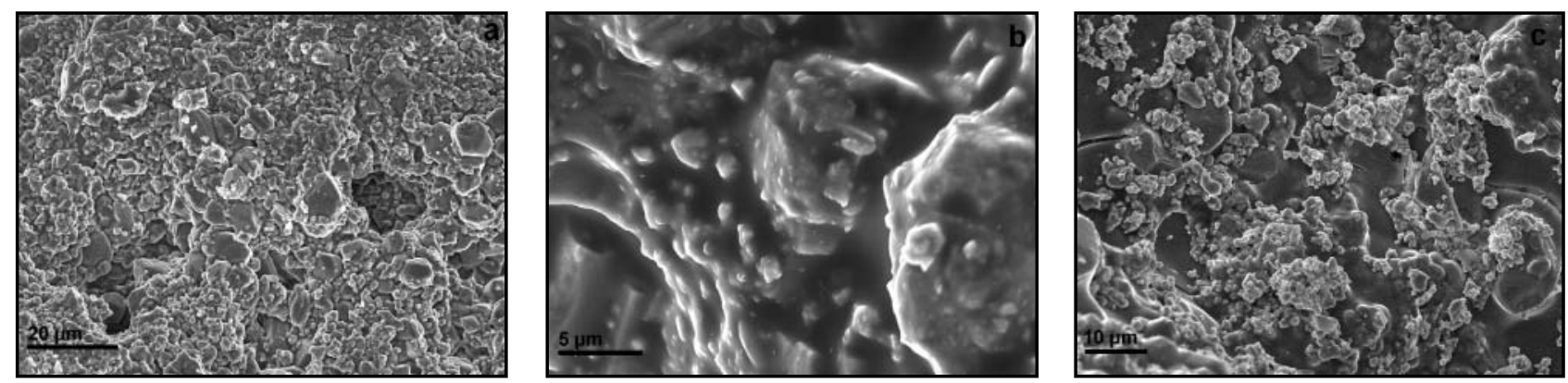

Figura 5. Microfotografías al MEB de calcarenitas tratadas con productos consolidantes, hidrofugantes y alteradas. (a): imagen general de una muestra alterada con ciclos de hielo-deshielo y tratada con Tegovakon $\mathrm{V}$ por inmersión, en la que se observa el producto polimerizado pero no forma una capa continua que envuelve toda la muestra; (b): una muestra alterada con ciclos de atmósfera contaminada con $\mathrm{SO}_{2}$ y tratada con Tegosivin $\mathrm{HL} 100$ pulverizado, en la que se aprecia como el tratamiento ha cubierto totalmente la superficie; (c): muestra alterada por ciclos de cristalización de sulfato sódico y tratada con Silo 111 pulverizado, en la que se observa la presencia de grietas en la capa de producto y el desarrollo de cristales de sales en las zonas donde no ha actuado el tratamiento.

Figure 5. SEM micrographs of calcarenite samples aged after treatment with consolidants or water repellents: (a) sample subjected to freeze-thaw ageing and immersed in Tegovakon $V$, showing that even though polymerization took place, the product failed to form a continuous layer over the entire surface; (b) $\mathrm{SO}_{2}$ pollution-aged sample sprayed with Tegosivin $\mathrm{HL}$ 100, which covered the surface completely; (c) sample subjected to sodium sulphate crystallization ageing and sprayed with Silo 111, showing cracks in the coating and salt crystals developing in areas where the treatment was ineffective.

Se ha observado en el MEB que los tratamientos aplicados por inmersión penetran a mayor profundidad, lo que confirma los datos de incremento de peso de las muestras tratadas de la tabla 2. Por otra parte, la aplicación por pulverización produce un tapizado más uniforme de la superficie de las muestras e incluso penetra fácilmente en las grietas existentes en su superficie externa (Figura 5b).

En algunos casos de muestras sometidas a alteración mediante ciclos de cristalización de sales se ha observado la migración de las sales que permanecían en el seno de las probetas hasta la superficie conforme se suceden los ciclos, y su eclosión a través de las fisuras y poros que se generan en la película del producto aplicado (Figura $5 c$ ).
According to the SEM findings, the immersion treatments penetrated the stone more deeply, which is consistent with the increase in weight recorded in Table 2, although spraying provided a more uniform cover and penetrated the outer cracks more readily (Figure $5 b$ ).

In some of the specimens subjected to salt crystallization ageing, salts were observed to gradually migrate from the stone core closer to the surface after each cycle and finally effloresce through the cracks and pores in the treatment (Figure 5c). 


\subsection{Parámetros hídricos de las muestras tras finalizar los ensayos de envejecimiento}

En cuanto al comportamiento hídrico de las calcarenitas, en la figura 6 se puede apreciar cómo la cinética de captación y pérdida de agua en todas las probetas tratadas y posteriormente envejecidas, para cualquiera de los ensayos que se considere, se ha modificado sustancialmente en comparación a la calcarenita utilizada como blanco (Figura 1). Se destaca, de manera generalizada, una disminución de la cantidad final de agua absorbida. La velocidad de secado de las calcarenitas está condicionada por el tipo de ensayo de envejecimiento al que han sido sometidas, siendo más rápida tras el ensayo de cristalización de sales; aunque continua siendo más lento el proceso respecto a la muestra utilizada como blanco (hecho negativo dado que es deseable que los materiales pétreos se sequen lo más rápidamente posible para disminuir el tiempo de contacto con el agua y las sales que puede llevar disueltas) sobre todo en el caso en que se haya aplicado el Tegosivin HL 100.

\subsection{Water sorption parameters after accelerated ageing}

As Figure 6 shows, water uptake and loss kinetics were substantially different from the control calcarenite (Figure 1) in all the treated samples, regardless of the ageing procedure used. As a rule, a smaller final amount of water was absorbed. Calcarenite drying rates depended on the type of ageing, with the shortest times recorded for the salt crystallization specimens, particularly the ones treated with Tegosivin HL 100, which nonetheless took longer to dry than the control sample. This finding has adverse implications, for stone building materials should dry as quickly as possible to reduce the time they are in contact with water and the dissolved salts it may carry.
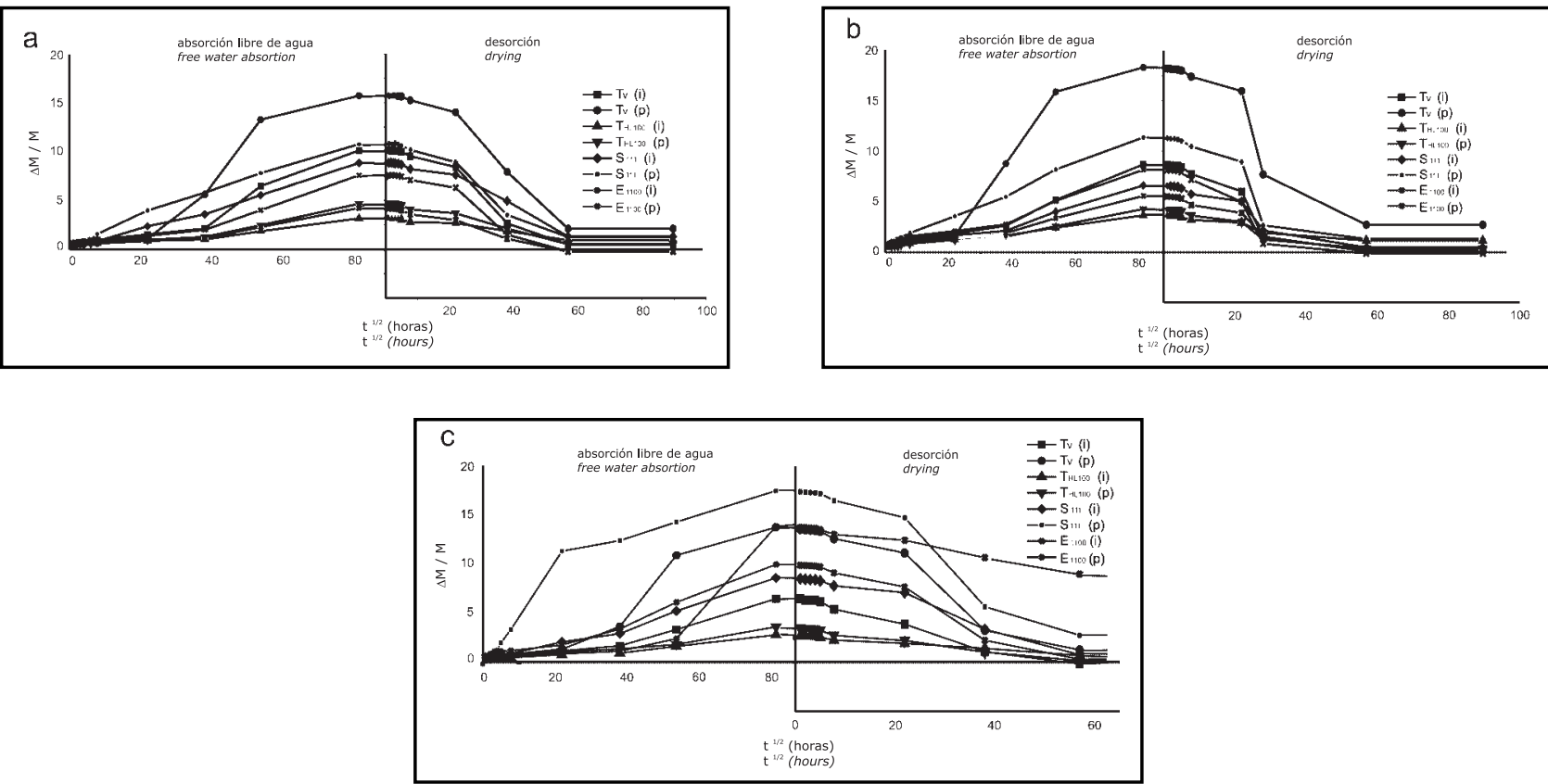

Figura 6. Curva de absorción y desorción libre de agua de la calcarenita de Santa Pudia sometidas a ciclos de hielo-deshielo (a), cristalización de sales (b) y atmósfera contaminada con $\mathrm{SO}_{2}$ (c), después de aplicarles los tratamientos de consolidación y protección. Incremento de peso $(\Delta \mathrm{M} / \mathrm{M})$ versus la raíz cuadrada del tiempo expresada en horas $\left(\mathrm{t}^{1 / 2}\right)$. Cada una de las curvas recoge el valor medio

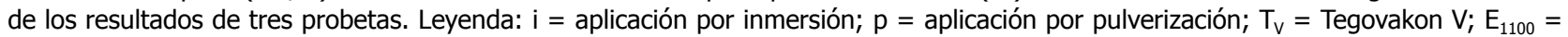
Estel 1000, $\mathrm{S}_{111}=$ Silo 111; $\mathrm{T}_{\mathrm{HL} 100}=$ Tegosivin HL100.

Figure 6. Free water absorption and desorption curves for consolidant- or water repellent-treated Santa Pudia calcarenite after (a) freeze-thaw, (b) salt crystallization and (c) $\mathrm{SO}_{2}$ pollution ageing procedures. Increase in weight $(\Delta M / M)$ against the square root of time in hours ( $\left.t^{1 / 2}\right)$. Values represent the mean of three replicates. Legend: $i=$ immersion; $p=$ spray; $T_{V}=$ Tegovakon $V ; E_{1100}=$ Estel 1100 , $S_{111}=$ Silo 111; $T_{H L 100}=$ Tegosivin HL 100.

Se pueden señalar algunas otras diferencias en el comportamiento hídrico. Así, se aprecia cómo el consolidante Tegovakon $\mathrm{V}$ es menos efectivo en la función de inhibir la
Other sorption differences were likewise observed. According to the present findings, for instance, Tegovakon $V$, a consolidant, protected the samples from 
penetración del agua en las probetas; en pocas horas se alcanza el mismo grado de saturación que presentan el grupo de las probetas sin tratar.

Los productos hidrofugantes tienen una eficacia muy dispar: el Silo 111 se comporta peor que el Estel 1100 (producto con función mixta de consolidante e hidrofugante), mientras que el Tegosivin HL 100 es el que menor volumen de agua permite que penetre en las probetas. Todo ello, al margen de la metodología que se haya adoptado para su aplicación (Figs. 6a, 6b y 6c).

Al finalizar el ensayo se ha observado que la desorción de las probetas únicamente es total con el Tegosivin HL 100. En los casos en que se ha aplicado el Estel 1100 mediante pulverización puede llegar a retener casi un $10 \%$ de agua en el interior de las probetas (Figura 6a); con los productos Silo 111 y Tegovakon $\mathrm{V}$ los valores se sitúan ligeramente por debajo del 4\% (Figuras 6a y 6b).

\section{COLORIMETRÍA}

A simple vista se aprecia que la aplicación de los tratamientos produce un oscurecimiento en la superficie de las calcarenitas. La colorimetría ha permitido cuantificar la variación, tanto de la cromaticidad ( $a^{*}$ y b*) como de la luminosidad $\left(L^{*}\right)$. En la Tabla 3 se recogen los valores medios de $L^{*}, a^{*} y b^{*}$ de las muestras utilizadas como blanco, de las envejecidas y de las tratadas después del envejecimiento. En efecto, cualquiera de los productos water penetration less effectively, for within a few hours they reached the same saturation rate as the untreated samples.

The performance of the water repellents varied widely: Silo 111 was less effective than Estel 1100 (combined consolidant and water repellent), while the Tegosivin HL 100-treated specimens exhibited the smallest water uptake. The above order of effectiveness was observed for both application methods (Figures 6a, $6 b$ and $6 c$ ).

When the test was over, full desorption was observed in the Tegosivin HL 100 specimens only. The samples sprayed with Estel 1100 retained up to $10 \%$ of the water (Figure 6a), while the figure for Silo 111 and Tegovakon $V$ was slightly less than 4\% (Figures $6 a$ and $6 b$ ).

\section{COLORIMETRY}

The calcarenite surface darkened visibly after application of the treatments. Colorimetric techniques were used to measure variations in chromaticity ( $a^{*}$ and $\left.b^{*}\right)$ and lightness $\left(L^{*}\right)$. Table 3 gives the mean $L^{*}, a^{*}$ and $b^{*}$ values for the controls, the aged samples, and the samples treated after ageing. The value of parameter $L^{*}$ declined after application of all the treatments, more moderately with Tegovakon $V$ and more sharply with Tegosivin $H L$

Tabla 3 / Table 3

Valores medios de luminosidad $\left(L^{*}\right)$ y cromaticidad ( $a *$ y $b^{*}$ ) de las calcarenitas sin alterar ("blanco") y envejecidas. Tratadas por pulverización $(p)$ o inmersión (i) mediante Tegovakon V $\left(T_{\mathrm{V}}\right)$, Estel $1000\left(\mathrm{E}_{1100}\right)$, Silo $111\left(\mathrm{~S}_{111}\right)$ y Tegosivin HL100 $\left(\mathrm{T}_{\mathrm{HL} 100}\right)$.

Average lightness $\left(L^{*}\right)$ and chromaticity ( $a^{*}$ and $\left.b^{*}\right)$ values in freshly quarried (control) and aged stone after spraying with $(p)$ or immersion in (i) Tegovakon V $\left(T_{V}\right)$, Estel $1100\left(E_{1100}\right)$, Silo $111\left(S_{111}\right)$ or Tegosivin HL100 $\left(T_{H L 100}\right)$.

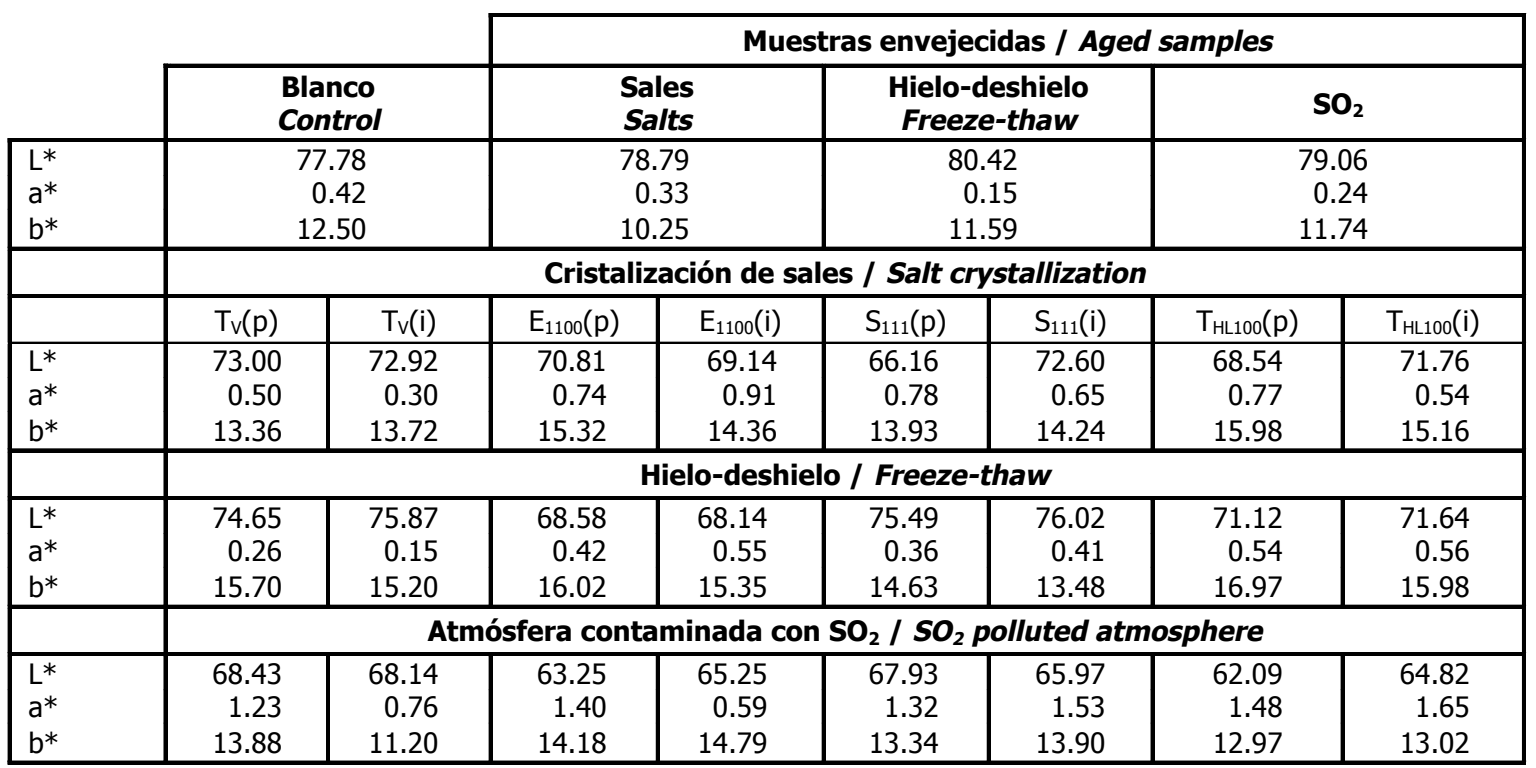


aplicados causa una disminución del parámetro L*. Esta disminución es menos acentuada cuando se aplica el Tegovakon $\mathrm{V}$ y más marcada si los productos empleados son el Tegosivin HL100 y el Estel 1100 . Por otra parte, no se observa una tendencia nítida en función de la técnica de aplicación: en ocasiones oscurece más la pulverización, otras veces la inmersión; esto se debe a la mayor o menor cantidad de producto que polimeriza en la superficie de las muestras. En cualquier caso, las diferencias de L* entre ambas metodologías de aplicación son mínimas.

En cuanto a los parámetros de la cromaticidad, se registran también algunos cambios pero son menos acentuados que los de la luminosidad. En todos los casos el color tiende a desplazarse hacia tonos más rojo-amarillentos, debido al incremento de los parámetros a* y b*.

A partir de la comparación de los tres tipos de ensayos de envejecimiento acelerado, se establece que los ciclos de atmósfera contaminada con $\mathrm{SO}_{2}$ han producido las mayores modificaciones colorimétricas. En este último caso las calcarenitas son las de menor valor de $L^{*}$ y muestran el mayor aumento del parámetro a*.

\section{CONCLUSIONES}

Todos los productos de consolidación y/o hidrofugación evaluados en este trabajo confieren una mejoría apreciable en la durabilidad de la calcarenita de Santa Pudia frente a los ensayos de envejecimiento acelerado en laboratorio.

El método de aplicación por inmersión de las probetas les proporciona en la mayoría de los casos una durabilidad mayor en comparación con la impregnación mediante pulverización.

El producto que penetra en mayor cantidad y más adecuadamente en las probetas previamente alteradas es un hidrofugante: el Tegosivin HL 1100. En cuanto a los dos consolidantes, son ligeramente más positivos los datos del Estel 1100, excepto en las muestras degradadas en los ensayos de cristalización de sales y aplicado este producto mediante pulverización.

Las modificaciones cromáticas que originan los diversos productos de tratamiento son mínimas. Las más significativas se refieren a la disminución del parámetro L* (luminosidad) no alcanzando en ningún caso variaciones superiores al $10 \%$ del valor inicial.

Respecto a los productos de hidrofugación ensayados, Tegosivin HL 100 y Silo 111, el que mejores resultados ha proporcionado frente al agua y mayor persistencia en su
100 and Estel 1100. No clear pattern could be identified with regard to the application method. At times spraying darkened the stone more than immersion, while at others the opposite was observed. The degree of colour change depended on the degree of product polymerization on the surface of the samples. In any event, the $L^{*}$ values recorded for the two methods differed only slightly.

The variations found in chromaticity were smaller than the changes in lightness. The values of parameters $a^{*}$ and $b^{*}$ rose in all cases, which translated into more reddish-yellow tones.

The most intense colour changes were observed for the specimens subjected to $\mathrm{SO}_{2}$ pollution, where the $L^{*}$ value was the lowest and increase in parameter $a^{*}$ the largest.

\section{CONCLUSIONS}

All the consolidant and/or water-repellent products analyzed in this study significantly enhanced the durability of Santa Pudia calcarenite exposed to accelerated ageing.

In most cases, immersion improved durability more effectively than spraying.

Larger amounts of Tegosivin HL 100, a water repellent, penetrated the aged specimens and did so to a greater depth than any of the other treatments. Of the two consolidants, Estel 1100 performed slightly better than Tegovakon $V$, except in sprayed specimens exposed to salt crystallization.

Only minor chromatic variations were observed after application of any of the treatments. The most significant change was the decline in L* (lightness), which never exceeded $10 \%$ of the initial figure.

Of the two water repellents tested, Tegosivin HL 100 performed better and had a longer-lasting effect than Silo 111 , which was even less effective than the consolidants 
efectividad ha sido el Tegosivin HL 100. Por el contrario, respecto al producto Silo 111 , a causa de su comportamiento en determinados ensayos de envejecimiento acelerado y del conjunto de valores que se han medido en los posteriores ensayos hídricos, se concluye que es menos eficaz, incluso que los productos consolidantes ensayados.

En relación al consolidante más adecuado para ejercer sus funciones de reagregación en este litotipo calcáreo su elección resulta más problemática. Parece más aconsejable el empleo de Tegovakon $\mathrm{V}$, fundamentalmente por dos motivos: por que está demostrado que es totalmente compatible con el Tegosivin (ambos productos los fabrica la misma empresa) y por que presenta en los ensayos de inmersión de las probetas en agua una velocidad de secado más elevada que el otro producto consolidante ensayado, mientras que el Estel 1100 es susceptible de retener casi un $10 \%$ de agua en los poros y fisuras de la calcarenita con posterioridad al ensayo de envejecimiento acelerado en atmósfera contaminada con $\mathrm{SO}_{2}$. No se debe olvidar que la contaminación es uno de los principales factores de deterioro de la piedra ornamental de Santa Pudia.

\section{AGRADECIMIENTOS}

Este trabajo ha sido financiado por el Grupo RNM179 de la Junta de Andalucía y del Proyecto de Investigación MEC MAT2004-6804. Agradecemos a Nigel Walkington por la traducción del manuscrito. studied in terms of its behaviour in aged specimens and the results of the water sorption tests conducted.
The choice of the best consolidant for this type of calcareous stone is less straightforward, however. Tegovakon $V$ would seem to be the most suitable, on the one hand, because it has been shown to be totally compatible with Tegosivin (made by the same manufacturer). And on the other, in the water immersion tests, the specimens treated with this product dried faster than the ones coated with Estel 1100, the other consolidant studied. Indeed, when aged by $\mathrm{SO}_{2}$ pollution, the latter retained up to $10 \%$ of the water in cracks and pores. This finding is particularly relevant inasmuch as calcarenite, as noted above, is highly susceptible to pollution.

\section{ACKNOWLEDGEMENTS}

This research was funded by Regional Government of Andalusia Research Group RNM 179 and the Spanish Ministry of Education and Science under project MAT2004-6804. The authors wish to thank Nigel Walkington for his translation of the manuscript.

\section{BIBLIOGRAFÍA / BIBLIOGRAPHY}

(1) Laurenzi Tabasso, M.: "La conservazione dei materiali lapidei: aspetti scientifici e tecnici", Materiali Lapidei. Supplemento al n. 41 del Bollettino d'Arte. Problemi relativi allo studio del degrado e della conservazione. Vol. 1 (1987), pp. 1-10.

(2) Rossi Manaresi, R.: "On the treatment of stone sculpture in the past. Proceedings of the Meeting", The treatment of Stone, pp. 8195, Bologna, 1972.

(3) Cultrone, G., De La Torre, M. J., Sebastián, E., Cazalla, O., Rodríguez Navarro, C.: "Behavior of brick samples in aggressive environments", Water Air and Soil Pollution, Vol. 119 (2000), pp. 191-207. http://dx.doi.org/10.1023/A:1005142612180

(4) Simão, J., Ruiz Agudo, E., Rodríguez-Navarro, C.: "Effects of particulate matter from gasoline and diesel vehicle exhaust emissions on silicate stones sulfation", Atmospheric Environment, Vol. 40 (2006), pp. 6905-6917. http://dx.doi.org/10.1016/j.atmosenv.2006.06.016

(5) Lazzarini, L., Laurenzi Tabasso, M.: "Il restauro della pietra". CEDAM, Padova, 1986, 320 pp.

(6) Esbert, R. M. "The use of surface protectants: the current situation in Spain, Portugal and South America", Science and Technology for Cultural Heritage, Vol. 2 (1993), pp. 183-189.

(7) Esbert, R.M., Díaz Pache, F.: "Influencia de las características petrofísicas en la penetración de consolidantes en rocas monumentales porosas", Materiales de Construcción, Vol. 43 (1993), pp. 25-36.

(8) Valdeón, L., Esbert, R. M., Grossi, C. M.: "Hydric properties of some Spanish building stones: a petrophysical interpretation", Materials Issues in Art and Archaeology III, pp. 911-916, (1993).

(9) Villegas, R.: "Estudio de la alterabilidad y respuesta de tratamientos de conservación de los principales tipos de piedra utilizados en catedrales andaluzas", Tesis Doctoral, 400 p., Servicio de Publicaciones Universidad de Sevilla, Sevilla (1989).

(10) Rivas, T., Prieto, B., Silva, B.: "Permeability to water vapour in granitic rocks. Application to the study of deleterious effects in conservation treatments", Building and Environments, Vol. 36 (2001), pp. 239-246. http://dx.doi.org/10.1016/S0360-1323(00)00003-2

(11) Toniolo, L., Poli, T., Castelvetro, V., Manariti, A., Chiantore, O., Lazzari, M.: "Tailoring new fluorinated acrylic copolymers as protective coatings for marble", Journal of Cultural Heritage, Vol. 3 (2002), pp. 309-316. http://dx.doi.org/10.1016/S1296-2074(02)01240-2 
(12) Zendri, E., Biscontin, G., Nardini, I., Riato, S.: "Characterization and reactivity of silicatic consolidants", Construction and Building Materials, Vol. 21 (2007), pp. 1098-1106. http://dx.doi.org/10.1016/j.conbuildmat.2006.01.006

(13) Sebastián Pardo, E., Cultrone, G., Garibaldi, V., Rodríguez Navarro, C., de la Torre, M. J., Valverde, I.: "La caliza de Sierra Elvira: comportamiento petrofísico de una piedra significativa del Patrimonio Arquitectónico Andaluz", Materiales de Construcción, Vol. 58 (2008), pp. 51-63.

(14) Sebastián, E., Zezza, U., Rodríguez-Navarro, C., De la Torre, M. J., Cardell, C.: "La "Piedra Franca", biocalcarenita, en la construcción de edificios históricos de Granada", I Congreso Internacional Rehabilitación del Patrimonio Histórico y Edificación no 1 (1992), pp. $329-336$. (15) Rodríguez Navarro, C.: "Causas y mecanismos de alteración de los materiales de calcáreos de las Catedrales de Granada y Jaén", Tesis Doctoral, p. 412, Universidad de Granada, 1994.

(16) UNE 22-185-85: Mármoles y calizas ornamentales. Resistencia a la compresión. A.E.N.O.R., Madrid (1985).

(17) Rodríguez Navarro, C., Cardell, C., García Ruiz, J. M., Rodríguez Gordillo, J.: "Experimental study of salting out processes on biocalcarenite". III Reunión Nacional de Crecimiento Cristalino, Vol. 23 (1993).

(18) Leary, E.: "A preliminary assessment of capillarity tests as indicators of the durability of British limestones", The Conservation of Stone, II A (1981), pp. 75-85.

(19) Alonso, F. J., Esbert, R. M., Ordaz, J.: "Comportamiento hídrico de calizas y dolomías", Boletín Geológico y Minero, Vol. 98 (1987), pp. 555-576.

(20) NORMAL 7/81: Assorbimento d'acqua per immersione totale. Capacità di imbibizione. CNR-ICR, Roma, 1981, 5 pp.

(21) NORMAL 29/88: Misura dell'indice di asciugamento (Drying Index). CNR-ICR, Roma, 1988, 9 pp.

(22) RILEM: Recommended tests to measure the deterioration of stone and to assess the effectiveness of treatment methods. Commission 25-PEM: Protection et Erosion des Monuments, 1980, pp. 175-253.

(23) UNE 67-028-84: Ladrillos de Arcilla cocida. Ensayos de heladicidad. A.E.N.O.R., Madrid, 1984.

(24) UNE 7-136-58: Estabilidad de áridos frente a disoluciones de sulfato sódico o sulfato magnésico. A.E.N.O.R. Madrid, 1958.

(25) DIN 50018. Testing in a saturated atmosphere in the presence of sulfur dioxide. pp. 3. 1997.

(26) Esbert, R. M., Ordaz, J., Alonso, F. J., Montoto, M.: "Manual de diagnosis y tratamiento de materiales pétreos y cerámicos". Col-legi d' Aparelladors i Arquitectes Tècnics de Barcelona. Barcelona, 1997.

(27) Villegas, R.: "Metodología para la evaluación y estudio previo de tratamientos", Cuadernos Técnicos: Metodología de diagnóstico y evaluación de tratamientos para la conservación de los edificios históricos, Vol. 8, pp. 194-207, 2003.

(28) Durán Suárez, J. A.: "Estudio de consolidantes y protectivos para la restauración del material pétreo", Tesis Doctoral, p. 370, Universidad de Granada, 1996.

(29) Sebastián, E., De la Torre, M. J., Cazalla, O., Cultrone, G., Rodríguez, C.: "Evaluation of treatments on biocalcarenites with ultrasound", 6th International Conference on "Non-destructive testing and microanalysis for the diagnostics and conservation of the cultural and Environment Heritage", pp. 357-370, 1999.

(30) Benavente, D., García del Cura, M. A., Fort, R., Ordóñez, S.: "Durability estimation of porous building stones from pore structure and strength", Engineering Geology, Vol. 74 (2004), pp. 113-127. http://dx.doi.org/10.1016/j.enggeo.2004.03.005 